\title{
El fin de la historia en la Nueva corónica y buen gobierno de Felipe Guaman Poma de Ayala
}

\author{
Rolena AdoRno \\ Yale University \\ rolena.adorno@yale.edu \\ $\&$
}

\section{Resumen}

El mapamundi de la Nueva corónica y buen gobierno combina y celebra una gran constelación de imágenes e ideas. Guaman Poma lo construye gráficamente, aprovechando la representación simbólica del espacio de la Europa medieval igual que la cosmología y cosmografía andinas. Guaman Poma complementa la organización espacial del mapamundi pictórico con formulaciones de valor temporal: su conceptualización de tiempos pasados, "las edades del mundo" en la Nueva corónica, y la de tiempos futuros, en el capítulo de "Conzederaciones" morales en el Buen gobierno. Propongo que el enigmático mapamundi es el ápice de la obra, la culminación simbólica que resume y condensa la compleja visión de su autor. Postulo, además, que el mapamundi presenta su conceptualización profética del "fin de la historia," es decir, el cumplimiento del destino histórico y trascendental de "las Indias del Perú".

Palabras claves: Nueva corónica y buen gobierno, mapamundi, Guaman Poma, Bartolomé de las Casas, Jerónimo de Chaves, "el fin de la historia”.

\section{Abstract}

Guaman Poma's mapamundi relied on symbolic medieval European representations of space as well as on Andean cosmology and cosmography. 
Rolena Adorno

He complemented the spatially organized, pictorial mapamundi with temporal formulations regarding the past in "the ages of the world" in the Nueva corónica, and the future, in the moral "Considerations" of the Buen gobierno. I propose that his enigmatic mapamundi is the symbolic culmination that summarizes and condenses his complex vision. I postulate, furthermore, that the mapamundi represents his prophetic conceptualization of "the end of history," that is, the fulfillment of the historical and transcendent destiny of "the Indies of Peru".

Keywords: Nueva corónica y buen gobierno, mapamundi, Guaman Poma, Bartolomé de las Casas, Jerónimo de Chaves, "el fin de la historia”.

Recibido: 25/10/14 Aceptado: 18/11/14 Publicado on line: 10/1/15

Presenciamos aquí una magnífica representación gráfica de mucha delicadeza (Figura 1). Se la puede apreciar, gracias a la alta calidad de la reproducción digital realizada por la Biblioteca Real de Copenhague en Dinamarca, donde el manuscrito se ha conservado desde la década de 1660 (Adorno 2002: 1823). (El manuscrito completo ha estado en línea desde mayo de 2001 y en 2004 agregamos, con correcciones, la transcripción del mismo que habíamos publicado John Murra, Jorge Urioste y yo en 1980.)

Tomemos un momento para enumerar los elementos de esta composición: una sirena nos aparenta saludar con la mano. Cerca de ella, sobre la tierra, en el bosque del Amazonas, vemos pasearse un gran mono, un unicornio, un hombre salvaje peludo, y un hipogrifo, junto con otros animales. Hay, por arriba, peces que parecen ser alados y un gran "pez de espada," como lo identifica Guaman Poma. Por abajo, hay dos carabelas conquistadoras, una de las cuales sale del puerto de Panamá, Portobelo. Vemos también una ballena, identificada como tal; tiene la cara y cuerpo de uno de los gatos dibujados por Guaman Poma (1615: 708) en otra oportunidad, pero con el detalle de las orejas convertidas en fuentes. Hay un animal que Guaman Poma identifica como "lobo"; querrá decir, lobo marino, o foca (Ccocha puma o açuka en González Holguín (1989:65). En total, vemos en su redondez el mundo natural: a la vez cielo y mar, sol y luna (es decir, día y noche), peces y animales cuadrúpedos, unos reales, otros míticos, y el mundo humano, habitado y ordenado por el hombre. Guaman Poma ha recreado a la perfección las fantasías que acompañaban las obras cartográficas de su época, a la vez que infunde su empresa, como veremos, con una gran seriedad.

Comencemos por repasar los elementos que todo lector atento de Guaman Poma ya conoce: Reconocemos las líneas cuadradas que representan latitud y longitud, es decir, la proyección cónica de los mapas realizada a partir de Ptolomeo, tanto como las líneas divisorias diagonales del imperio de Tawantinsuyu. Estas dos líneas divisorias diagonales son tales que la primera división crea los campos altos y bajos (teniendo la posición alta el 


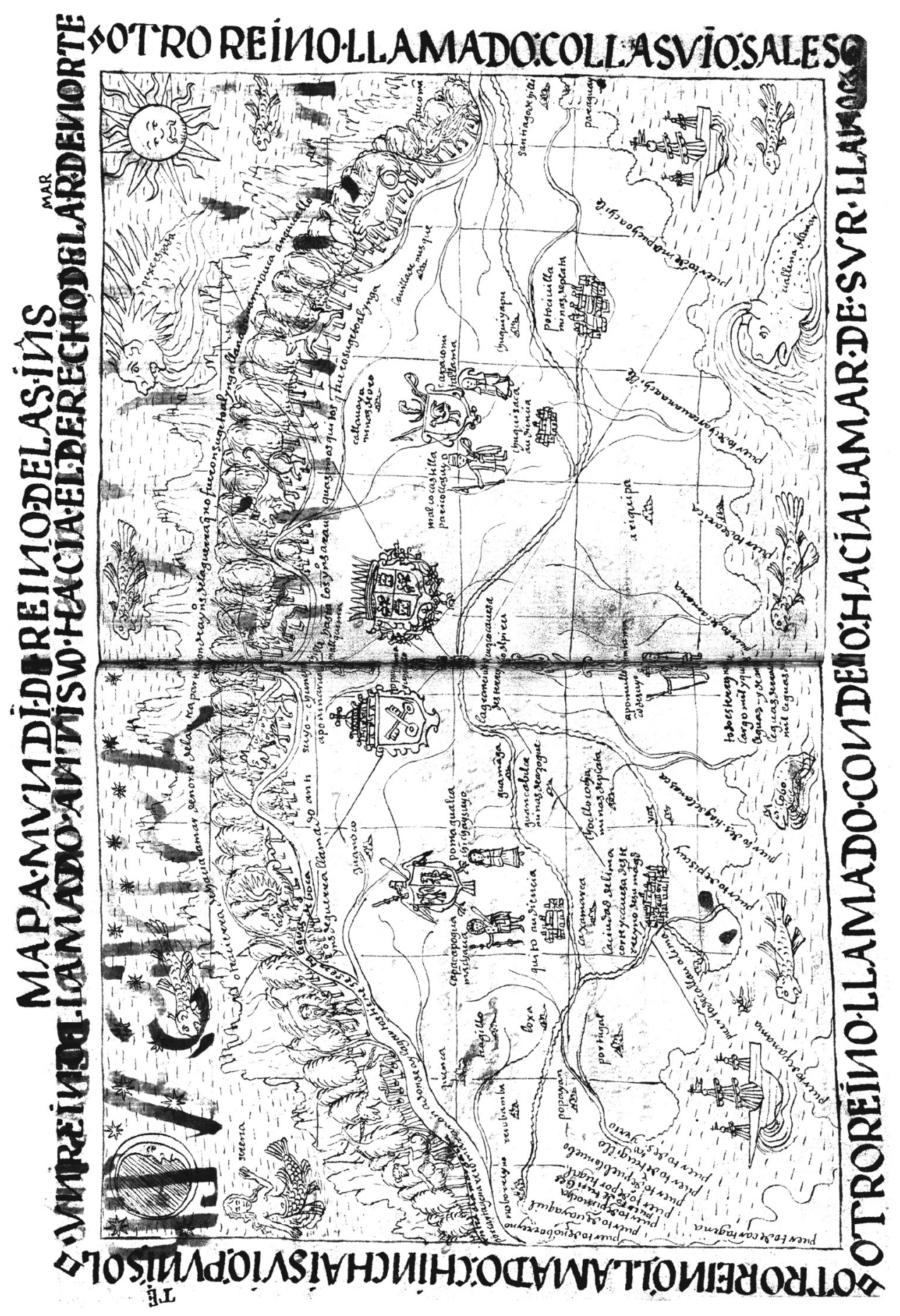


valor preferencial), mientras que la segunda, una intersección de la primera, simultáneamente determina el centro del diseño (el quinto sector), así como las posiciones de derecha e izquierda. Al coordinar las posiciones de derecha/ izquierda, con respecto al centro, con las de hanan o arriba y hurin, abajo, como lo han hecho los investigadores Juan Ossio (1973: 179) y Nathan Wachtel (1973: 177), se produce como resultado una jerarquía de valores que está confirmada por la corroboración de otras fuentes andinas de la época: el dibujo en la pared del Templo de Coricancha reproducido por Juan de Santacruz Pachacuti Yamqui en su Relación de antigüedades deste reyno del Perú y la descripción, por el Inca Garcilaso de la Vega en su Comentarios reales de los Incas, de la fundación y organización del Cuzco imperial.

El Inca Garcilaso ofrece la clave de la conjunción de los esquemas al juntarlos con los conceptos de masculino y femenino. Al hacerlo, reitera la dualidad sexual del esquema del dibujo del Templo de Coricancha. Así el concepto andino de hanan une las posiciones de arriba y derecha con la masculinidad y la superioridad o dominación y el de hurin con las posiciones de abajo e izquierda con la femineidad o subordinación. Aquí al respecto, en la "voz" de su tío Inca Cusi Hualpa, las palabras del Inca Garcilaso:

Desta manera se principió a poblar esta nuestra imperial ciudad, dividida en dos medios que se llamaron Hanan Cozco, que como sabes, quiere decir Cozco el alto, y Hurin Cozco, que es Cuzco el bajo. Los que atrajo el Rey quiso que poblasen a Hanan Cozco, y por esto le llamaron el alto; y los que convocó la reina, que poblasen a Hurin Cozco, y por eso le llamaron el bajo. Esta división de ciudad no fue para que los de la una mitad se aventajasen a los de la otra mitad en exenciones y preeminencias, sino que todos fuesen iguales como hermanos, hijos de un padre y de una madre .... y [el Inca] mandó que entre ellos hubiese sola una diferencia y reconocimiento de superioridad: que los del Cozco alto fuesen respetados y tenidos como primogénitos hermanos mayores; y los del bajo fuesen como hijos segundos; y en suma, fuesen como el brazo derecho y el izquierdo en cualquiera preeminencia de lugar y oficio, por haber sido los del alto atraídos por el varón, y los del bajo por la hembra (Vega 1963: 28).

Al analizar Ossio (1973) y Wachtel (1973) esta organización espacial andina en el mapamundi de Guaman Poma, igualmente han notado la repetición del modelo en la representación de los dos reinos del Perú y Castilla, en la del Consejo Real del Inca, en la versión de Guaman Poma de la "Ciudad del Cielo" cristiano y en el dibujo de "La villa rica enpereal de Potocchi", en el cual el Inca y los reyes de los cuatro suyu sustentan las columnas de Hércules (Guaman Poma 1615: 42, 366, 952, 1065). Si las instituciones y la cultura no-andinas están modeladas de acuerdo con los conceptos autóctonos andinos, entonces 
se podría, en principio, analizar todas las narraciones pictóricas para ver si pueden ser explicadas como variaciones del modelo. Así, efectivamente, lo hemos podido hacer (Adorno 1979a, 1979b, 1984, 1986, 1989; López Baralt 1979a, 1979b, 1982, 1988). La escala de los valores inherentes al esquema de la cuadrícula ha servido como una herramienta poderosa para interpretar los eventos representados gráficamente en los centenares de dibujos que forman una parte integral de las 1.200 páginas de la crónica.

En su mapamundi Guaman Poma identifica las antiguas jurisdicciones del Imperio Incaico, colocando Chinchaysuyu al oeste, Antisuyu al norte, Collasuyu al este, y Cuntisuyu al sur, y pintando a sus cuatro gobernantes, acompañados de sus esposas (véase Figura 1). El gobernador de Chinchaysuyu es el mismo Guaman Chaua, de quien Guaman Poma dice ser nieto; a su izquierda: la princesa Poma Gualca; encima de éstos figura el escudo de Chinchaysuyo, compuesto por el halcón (guaman) y el puma (poma) (Wachtel 1973: 175, 177). La misma disposición la observamos en las otras divisiones del Imperio; el nombre del personaje aparece con el dibujo que lo representa, así como sus armas. Podemos ver claramente el de Collasuyo y, con menos claridad, el de Condesuyo; el de Antisuyo estará escondido de nuestra vista por el cocido del manuscrito. El centro, ocupado por Túpac Inca Yupanqui y su esposa Mama Ocllo, completa el cuadro. Dos escudos de armas rodean la imagen del Inca: el del pontificado romano y el de monarquía española.

Veamos ahora aspectos del mapamundi que no se suele comentar: Lo curioso es el hecho de que el décimo Inca, Túpac Yupanqui, es el que ocupa el centro. Guaman Poma no eligió a Guayna Capac Inca, el último que completó su reinado, ni tampoco a su hijo Huascar Inca, el heredero legítimo. Aparte de ser aquéllos, junto con el príncipe Atahualpa, los que desencadenaron el caos que resultó en la pérdida del imperio-una razón negativa para no colocar a ninguno de los tres en el puesto privilegiado-la elección de Tupac Inca Yupanqui corresponde a valores positivos. Sugiere que el valor modélico que Guaman Poma presenta para el pasado andino es el del Inca que ordenó la sociedad al interior del imperio, esto es, su infraestructura, instituciones y servicios: el repartimiento de los recursos y productos, la provisión de medios de comunicación y transporte (caminos y puentes) y la administración de la justicia, dando nuevas leyes y honrando a las antiguas (Guaman Poma 1615: $335,358,352,366)$. No sorprende que la antigua capital del Cuzco, el umbilicus mundi, el ombligo del mundo como lo describió el Inca Garcilaso, sigue siéndolo. Pero lo que sí sorprende es que los escudos del monarca español y del papa romano no se identifican con la capital virreinal de Lima (que está en la periferia del mapa), sino que protegen, por así decir, los costados y la espalda de los antiguos reyes incaicos del Cuzco, que ocupa el centro. 
El próximo paso es ver cómo este mapamundi representa "el fin de la historia", o sea, un valor profético: $\mathrm{Al}$ anunciar mi tema hay quienes podrían haber pensado en Francis Fukuyama y su libro de 1992, The End of History and the Last Man (El fin de la historia y el último hombre). Al mencionarlo, debemos aclarar su concepto. Fukuyama concibe el fin de la historia de un modo secular y político: la democracia liberal sería el punto final de la evolución ideológica del hombre y la forma final, es decir, la más perfecta, del gobierno humano (Fukuyama 1992: xi). Para él "la historia" no significa el desenvolvimiento de los acontecimientos, que no terminará hasta el holocausto final ecológico o nuclear, sino, en cambio, el proceso evolucionario único y coherente que tomara en cuenta la experiencia de todos los pueblos en todos los tiempos. Su fuente es, por supuesto, Hegel, cuyo concepto lo hizo suyo Karl Marx, con la diferencia de que para Hegel ese "fin de la historia" era el estado liberal y para Marx, el comunismo (Fukuyama 1992: xii). La idea era, en cada uno de esos paradigmas, que no se evolucionaran más los principios e instituciones fundamentales, a pesar de las peripecias subsiguientes de la historia económica, social y política (Fukuyama 1992: xii). Es decir, el "fin de la historia" postulado por Fukuyama consiste en el establecimiento de los principios e instituciones del orden político-social deseado, teorizando que éste no evolucionará, independientemente de los eventos que pudieran seguir a su inauguración.

En realidad el concepto de Fukuyama tiene relación (aunque no lo menciona) con la propia noción medieval de la disposición del tiempo de la historia humana. Pero los medievales coordinaron el concepto de la temporalidad con la organización del espacio, y le dieron forma en sus mapamundi. El concepto gráfico del mapamundi consistió en comunicar información histórica dentro de un marco geográfico a la vez que la crónica lo hacía por medio de la cronología, comunicando ésta en una narración en prosa; los mapas comenzaban a publicarse juntos con los textos, una coordinación que se debía al impacto del humanismo y el nuevo interés por interpretaciones no estrictamente alegóricas sino literales (Black 1997: 5, 7). En la Nueva corónica y buen gobierno tenemos ambas cosas: mapa y crónica. La lectura del mapamundi de Guaman Poma depende de una coordinación parecida entre lo verbal y lo gráfico. Para destacar la originalidad de la síntesis creada por el cronista andino, veamos en su mapamundi en conjunto las múltiples resonancias de sus elementos andinos y europeos.

En cuanto a la conceptualización medieval cristiana del espacio vale recordar, siguiendo a Alain Milhou, que:

los teólogos de la Antiguiedad cristiana tardía y de la Edad Media . . . admitían la teoría griega de la Tierra como esfera cosmográfica. ... Pero conciliaban esta teoría con las creencias vetero-testamentarios sobre la 
tierra llana, con su centro en Jerusalén: si la 'tierra cosmográfica' era, para ellos, un globo, el ecúmeno (o sea la tierra habitable) no representaba más que una mínima parte de la superficie de la Tierra y podía, por lo tanto, ser considerado como un disco llano, colocado encima de la esfera. Esta conciliación de dos teorías, que nos parecen inconciliables, sería vigente hasta el redescubrimiento, a principios del siglo XV, de la Geografía de Ptolomeo (h. 150 d.C.) y no sería definitivamente descartada hasta los Descubrimientos de la segunda mitad del siglo XV (Milhou 1983: 404-405).

Sobre ese "disco llano" Jerusalén era el centro del mundo y en ese centro comenzó y terminó la historia humana: es decir, el término del Nuevo Testamento que designaba el advenimiento glorioso de Jesucristo al final de los tiempos (Moliner ed., 2:587), después de terminada la lucha contra el Anticristo. Cito a Milhou, de nuevo refiriéndose a los teólogos de la Antiguiedad cristiana tardía y de la Edad Media:

Para ellos Jerusalén terrestre, Jerusalén mesiánica y Jerusalén espiritual se confundían. Allí donde habría muerto Adán, conservándose su cráneo a los pies de la cruz, allí donde había muerto Cristo para la salvación de los hombres, en ese mismo sitio originario y primordial se acabaría la historia de la humanidad. El caminar hacia Jerusalén era por lo tanto como una vuelta a los orígenes, un retorno al paraíso perdido (Milhou 1983: 404; énfasis nuestro).

Guaman Poma crea un variante andino de este modelo. Es decir, después de llegar a la perfección del orden político, económico y social, no se podía llegar a más, a pesar de los eventos subsiguientes que terminaran, como terminaron, en las formas más agresivas y abusivas del colonialismo español.

Con esto en mente, Guaman Poma emprendió su interpretación de la historia del pasado andino y su proyección hacia el futuro. En mi argumento, repito, el mapamundi es la condensación -la síntesis- de toda su empresa. Tal como se desenvolvieron las aspiraciones de las Cruzadas y su objetivo de la recuperación temporal de la Tierra Santa en las correspondencias geográficas imperantes sobre el ecúmeno, habitable y llano, con su vuelta a los orígenes, el Cuzco sustituye el Jerusalén en el mapamundi de Guaman Poma. Al postularlo, el cronista andino propone la vuelta a los orígenes andinos y la recuperación del paraíso, es decir, la restauración del orden, explicitándolo, concretándolo, en la soberanía renovada de los príncipes andinos. Descubrimos la clave de su propuesta en el capítulo de las "Conzederaciones".

En una de sus "sentencias" o juicios morales Guaman Poma ensalza la grandeza de los reyes incas. Asevera que, en contraste con todos los otros "rreyes y príncipes, enperadores del mundo, así cristianos como del Gran Turco y del rrey chino, enperadores de Roma y de toda la cristiandad y de judíos y 
del rrey de Guinea", los reyes incas fueron los más grandes del mundo: "No e hallado a nenguno que aya cido tan gran magestad y sean menospreciado". Su criterio es muy preciso: los demás reyes, al encontrar a un rival por su poder, "luego le mata o procura matalle y luego le descorona y queda solo" en el mando (Guaman Poma 1615:962). Continúa, comentando cómo, al contrario, el Inca mandaba un gobierno cuadripartito, presentándolo como el orden perfecto. Destaca a Tupac Inca Yupanqui como el más grande de los Incas y lo identifica, además, como un ancestro suyo ("mi agüelo"): "Y no a cido tan gran magestad ni tan gran rrey y de tan alto corona como mi aguielo, rrey Topa Ynga Yupanqui, Guayna Capac, Yngas.Tenía uan magestad grandícimo" (Guaman Poma 1615: 962). Continúa, aseverando que el mayor de los cuatro reyes subordinados al Inca había sido Guaman Chaua, Yarovilca de Allauca Huánuco, a quien el Inca había nombrado como su primer ministro ("segunda persona”) y virrey. Guaman Poma (1615: 962) relata que el Inca mandó que éste y los tres otros príncipes fueran "coronados para aconpañamiento y grandeser la persona rreal y magestad del Ynga".

Asevera, además, que una vez que el Inca le había dado la corona a Guaman Chaua, "no se las quitaua jamás a sus hijos ni a sus nietos" (Guaman Poma 1615: 962). Concluye con esta reflexión sobre el imperio incaico: "Y ancí conzederando deste dicho mi agüelo [Tupac Yupanqui] para la grandesa del mundo y sea monarca de toda gente criada de Dios de los quatro partes del mundo" (Guaman Poma 1615: 962-963). De esta manera el cronista andino destaca el modelo perfecto de orden público y subraya muy claramente el carácter hereditario de la realeza andina y el papel de su propia ascendencia dentro de ella.

Inmediatamente después de contemplar el orden antiguo del imperio de los Incas, Guaman Poma (1615: 963) contempla el futuro, proponiendo que el rey don Felipe III sea "monarca del mundo", para "el gobierno del mundo y defensa de nuestra santa fe católica, servicio de Dios". Concretiza su propuesta de esta forma:

El primero, ofrezco un hijo mío, príncipe deste rreyno, nieto y bisnieto de Topa Ynga Yupanqui, el décimo rrey, gran sauio, el que puso ordenansas..., El segundo, un príncipe del rrey de Guinea, negro; el terzero, del rrey de los cristianos de Roma o de otro rrey del mundo; el quarto, el rrey de los moros de Gran Turco, los quatro coronados con su septro y tuzones (Guaman Poma 1615: 963).

¿Qué autoridad tendría este "monarca universal", encarnado en la persona de Felipe III? El rey don Felipe estará "en medio destos quatro partes del mundo". Los cuatro reyes serán iguales uno al otro, bajo el señorío del monarca universal. Cuando éste salga a pie, ellos también lo harán. Cuando salga a caballo, ellos igualmente lo harán, montados "con sus palios". 
Se ordenarán alrededor del monarca universal en esta configuración: "En la mano derecha, el rrey cristiano; detrás, el rrey moro; en la mano esquierda, el rrey de las Yndias; detrás, el rrey de Guinea negro" (Guaman Poma 1615: 963). Esta pompa y la ceremonia idealizadas son de estilo europeo, y el ordenamiento de las figuras -volvemos a las observaciones de Ossio (179-181)- es andino, pero el orden está trastornado. Es decir, habríamos esperado encontrar al rey de las Indias, "en la mano derecha", en la posición de hanan, Pero Guaman Poma lo pone "en la mano esquierda", en la de hurin. Es decir, Guaman Poma ha identificado al rey de los cristianos y al de los moros con la categoría tradicional andina de hanan, la posición jerárquicamente superior, y al "rey de las Indias" y al de Guinea o África con la categoría inferior de hurin. De acuerdo con Ossio (181), "esta inversión guarda relación con su concepción de la conquista y con la idea de que su mundo presente está al revés". Según Guaman Poma (1615: 963), este papel del monarca del mundo, con quien "ningún rrey ni enperador no se puede engualar" y encarnado en la figura de Felipe III, es simbólico, no jurisdiccional:

Porque el rrey es rrey de su juridición, el enperador es enperador de su juridición, monarca no tiene juridición; tiene debajo de su mano mundo estos rreys coronados. An de ser asalareados en la dicha corte para la grandesa de oniverso mundo de todas las naciones y géneros de personas; yndios, negros y españoles cristianos, turcos, judíos, moros del mundo. Conzederación para la grandesa de su magestad del rrey.

Es significativo que en esta conceptualización del mundo, la conversión universal a la fe cristiana no forma parte del orden abogado por Guaman Poma, quien imagina "la grandesa de oniverso mundo de todas las naciones y géneros de personas; yndios, negros y españoles cristianos, turcos, judíos, moros del mundo" (963).

Al revelar el carácter abarcador y globalizante del pensamiento de Guaman Poma, elimina al mismo tiempo toda duda sobre su supuesta ambivalencia ante el gran debate sobre la legitimidad de los Incas. Es decir, para Guaman Poma (1615:962) no hay debate porque no había rivalidades dinásticas: los Incas siguieron el mando de los antiguos reyes Yarovilca Allauca Huánuco e instalaron al príncipe y herederos de éstos, no quitándoles jamás el privilegio.

El ofrecimiento de su propio hijo como "el rey de las Indias" es, en efecto, la repetición, pero con una diferencia significativa, de la propuesta de fray Bartolomé de las Casas (1484-1566) para restaurar la soberanía del Inca, tal como lo había planteado en el Tratado de las doce dudas de 1562. Aquí es pertinente lo que descubrí hace más de tres décadas (Adorno 1978a: 128-130: Adorno, 1978b: 144-147): encontré que en su capítulo de las "Conzederaciones" Guaman Poma citó textualmente este tratado lascasiano, pero sin nombrar a su autor. Lo interpreté como una prueba de la circulación -en forma manuscrita 
(porque el dicho tratado no se publicó en su época)- de las ideas de Las Casas en el Perú, medio siglo después de su muerte, siendo Guaman Poma uno de sus lectores de generaciones posteriores. Pero ahora atribuyo un significado mayor al dato: su papel en la obra de Guaman Poma es puntual y a la vez abarcador.

Por un lado, la presentación de Guaman Poma de un candidato nuevo para ser el soberano del Perú efectivamente reemplaza los príncipes incaicos ya desaparecidos, el último de los cuales, Tupac Amaru Inca, había sido ejecutado por el virrey Francisco de Toledo en 1572. Segundo, el que lo reemplazará, tal como Guaman Poma lo propone, representará a la vez la dinastía incaica y una todavía más antigua; nomina para el puesto a su hijo, no sólo como un "bisnieto y nieto" de Tupac Inca Yupanqui sino también como descendiente de la dinastía anterior a los Incas, la de Yarovilca de Allauca Huánuco. Dejando aparte el carácter interesado del nombramiento de su propio hijo, Guaman Poma en efecto presenta la única alternativa razonable a la propuesta anterior de Las Casas: un sustituto para los príncipes incas ya desaparecidos y uno que cumple los criterios toledanos de la búsqueda de los más antiguos reyes legítimos de los Andes. Muy perspicazmente la propuesta de Guaman Poma toma en cuenta y combina esas iniciativas, de muchas décadas atrás, que reconocían, según los intereses, o la soberanía de los Incas o la de sus rivales o antecesores.

Volvamos a la propuesta de Las Casas. En ésta el rey de España sería el "señor universal", en reconocimiento del cual recibiría anualmente "ciertas parias de oro y plata, las que fueren según las leyes naturales razonables" (Casas 1958 [1562]: 535). En 1562 Las Casas (536) había concluido su obra con una advertencia sobre cómo sacar al Inca de los Andes (se refería a Titu Cusi Yupanqui, nieto de Huayna Capac Inca, hijo de Manco Inca y hermano mayor del joven príncipe Tupac Amaru) y cómo evangelizarlo pacíficamente para poder llevar a todos los indios del Perú a la salvación cristiana. Tan grande, opinaba Las Casas, era el amor y la reverencia del pueblo andino por el Inca que fácilmente se podía efectuar entre sus súbditos una conversión masiva al cristianismo, porque, dice el fraile dominico, los indios al Inca "le aman y le reverencian y obedecen tanto, aun allá dentro donde está [en Vilcabamba], que por no ser él cristiano no lo son los demás" (Casas 1958 [1562]: 536).

La propuesta de Guaman Poma es la versión, actualizada cincuenta años más tarde, de la de Las Casas. El triunfo del cristianismo en los Andes (no en el resto del mundo, como ya vimos) es una de las aspiraciones más frecuentemente expresadas en la Nueva corónica y buen gobierno; lo reconoce todo lector que atienda a los "prólogos" con que Guaman Poma concluye la mayoría de los capítulos de su obra. Esto añade otro nivel de significación al mapamundi: el futuro que proyecta es a la vez una vuelta a los orígenes y el logro del paraísoun paraíso recuperado (el reinado de los herederos de las realezas andinas) y 
un paraíso prometido (la cristiandad, la salvación cristiana). Este es el sentido, creo yo, de presentar Guaman Poma en el mapamundi al Inca Tupac Yupanqui junto con los escudos de Castilla y de la Iglesia romana. Volveremos a este tema más adelante.

En cuanto a las postulaciones temporales que se encuentran en la crónica de Guaman Poma, varios investigadores (Mónica Barnes, David Fleming, Sophie Plas) han averiguado que Guaman Poma aprovechó una obra que, en las palabras de Barnes (1995: 291), quiso fijar "el lugar del hombre en el universo". Esta fuente la encontramos en la Nueva corónica, en el "Capítulo de las edades del mundo" (Guaman Poma 1615: 22-32), y es la obra del cosmógrafo sevillano, Jerónimo de Chaves. Chaves publicó en 1548 su Chronografía o reportorio de los tiempos el más copioso y preciso que hasta agora ha salido a luz. Plas (1996: 97) lo ha llamado una "fuente indiscutible de una parte del manuscrito" de Guaman Poma y, al dedicarse al mismo tema, Fleming (1994: 48-50) ancla su argumento sobre el uso de Guaman Poma del almanaque de Chaves en un dato convincente: la genealogía peculiar de los reyes de la Persia formulada por Chaves está repetida letra por letra por Guaman Poma.

Veamos sus particularidades: Fleming (1994: 57) observa que Guaman Poma incluye una novedad que Chaves había introducido en su obra, pero que no está presente en ninguna de las obras clásicas. Se trata de la opinión de Chaves (o de una fuente secundaria que utilizó) acerca de la identidad de uno de los reyes persas en relación al Antiguo Testamento. Chaves (citado por Fleming 1994: 57) había escrito "Artaxerxes reyno. fue llamado Assuero" y Guaman Poma (1615: 31) copia, al pie de la letra, "artagerges rreyno, fue llamado assuero". Esta peculiaridad dinástica demuestra convincentemente el empleo por Guaman Poma del almanaque del sevillano; resulta que el cronista andino toma directamente de Chaves todas las secuencias de los emperadores romanos, los pontífices cristianos y los reyes españoles (Fleming 1994: 57).

¿Qué habría querido lograr Guaman Poma con estas comparaciones dinásticas? Es obvio a todo lector que el cronista andino quería insertar la historia andina dentro de la tradición histórica judeo-cristiana. ¿Pero la historia persa? Guaman Poma omite las fechas de estas cronologías, y Fleming (1994: 51-53) postula que, por estas omisiones, Guaman Poma pudo presentar el reinado del Imperio Inca como tan antiguo como -y paralelo a- la historia del cristianismo. Su argumento es el siguiente (Fleming 1994: 52-53): Guaman Poma modificó el sistema de Chaves, que consistía en seis edades, en el cual la sexta comenzó con el nacimiento de Jesucristo. Como Chaves, Guaman Poma inauguró la quinta edad con Ciro de Persia. Pero para crear la sincronía entre los reyes incaicos y los bíblicos y antiguos, el cronista andino tuvo que convertir la quinta y sexta edades de Chaves en una sola. 
Con esta modificación Guaman Poma inauguró la sexta edad con la llegada de los españoles al Perú, pero, más importante, concibió las vidas de los Incas como extremadamente largas para que Julio César, el fundador de la Roma imperial, y Manco Capac, el fundador del Cuzco imperial, fueran contemporáneos, y para que el nacimiento de Jesucristo, ocurrido durante el reinado del segundo emperador romano, César Augusto, ocurriera durante el reinado del segundo Inca, Sinche Roca (Fleming 1994: 53). En un tour de force alucinante Guaman Poma acomodó en la quinta edad del mundo el reinado de los reyes persas desde Ciro en adelante, la inauguración del imperio romano con Julio César y César Augusto y la fundación del imperio de los Incas con Manco Capac y Sinche Roca, para que este último fuera coincidente con el romano y por consiguiente, coincidente con el nacimiento de Jesucristo.

No obstante, en el capítulo de las "Conzederaciones" del Buen gobierno, que ya citamos por su actualización del modelo lascasiano para la recuperación de la soberanía andina en el Perú, Guaman Poma propone otro esquema más de generaciones y edades. Este no consiste en cinco épocas sino en diez, no se trata de "las edades del mundo", que encontramos en la Nueva corónica, sino, aquí en el Buen gobierno, las edades de "las Indias del Perú" (Guaman Poma 1615: 925). Significativamente, este esquema inaugura el capítulo, siguiendo su frontispicio, que está elegantemente caligrafiado (Guaman Poma 1615: 923), seguido por el dibujo del Dios Padre trinitario sobre el trasfondo del paisaje de la sierra andina. Con su cabeza entre las estrellas más arriba de las nubes y sus pies, rodeados de criaturas (una mariposa, un caracol, dos insectos motivos gráficos clásicos andinos-), sobre la tierra, este Dios Padre alza los brazos con el sol en una mano, la luna en la otra (Guaman Poma 1615: 924). Tal es el marco que anuncia el "Capítulo primero de las Conzederaciones" que retoma y extiende las cinco edades andinas enumeradas en la Nueva corónica (Guaman Poma 1615:48-80); tal es la importancia para Guaman Poma de estas diez edades de "las Indias del Perú". Las primeras cinco consisten en las cuatro épocas preincaicas mas la incaica.

La sexta es "la era de las luchas", es decir, la guerra civil entre los hermanos incas Huascar y Atahualpa. Szeminski (1993:258) traduce así el texto mixto español-quechua de Guaman Poma: "Sexto: generación del cataclismo universal: tiempo de los Incas: Chalco Chima, Quisquis, Aua Panti, capitanes, durante el reinado de Topa Cuci Gualpa Uascar Inca legítimo, y de la contradicción con su [hermano] Atagualpa, Inca bastardo, tiempo de guerras mutuas y del mundo volteado". La séptima es la era de la conquista cristiana del Perú; Szeminski (1993:258) traduce el texto: "Séptimo: generación de la conquista cristiana por Don Francisco Pizarro y Don Diego de Almagro, y Don Luis de Ávalos de Ayala, gente del tiempo de la reina Doña Juana y del emperador Don Carlos”. La 
octava concierne la la guerra civil entre los conquistadores: "Octavo: el tiempo de rebelarse y alzarse contra nuestro rey, y convertirse en enemigos en la época cristiana” (Szeminski 1993: 258)."la era de los hombres que se hicieron la guerra", en Urioste ( $\mathrm{xx}$ ). La novena se caracteriza como la de la justicia cristiana; en ésta, nombra a los reyes castellanos del Perú hasta el momento (el emperador Carlos V, los reyes Felipe II y Felipe III).: "Noveno: Estar bien con buena y $i i$ justicia cristiana. Señor y rey, el señor Rey emperador Don Carlos, su hijo el Rey Don Felipe Segundo, su hijo Don Felipe Tercero, viven para nosotros y guardan que seamos buenos cristianos con su realeza" (Szeminski 1993: 259).; La décima edad es la de la "conciencia cristiana" (Guaman Poma 1615: 925).

Ossio (1973: 198-200) había interpretado el carácter de estas secuencias como mítico, ysu argumento se basa en la conceptualización y descripción espaciales: Opina que, por el ordenamiento del rey español rodeado por los cuatro reyes del universo cristiano, Guaman Poma (1615: 963) recuerda cómo dispuso al Inca en los dibujos del mapamundi y en el de Consejo del Inca, rodeado de los reyes de los cuatro suyos y concluye: "aunque se mencionan nombres concretos (Túpac Inca Yupanqui y Felipe III), Guaman Poma está tratando de destacar el carácter arquetípico de la noción Inca, es decir el carácter de 'Principio ordenador o unificador' de la noción Inca" (Ossio 1973: 200).

En este esquema de diez edades de las Indias del Perú, es cierto que la décima no tiene contenidos históricos, pero vale la pena examinar las dos frases en quechua que la constituyen: "El décimo, cristiano cayninchic yallin miran. Cayta yuyaycunqui soncoyqui ánimayquipe"; Guaman Poma traduce al castellano sólo la segunda: "Aués de considerar en tu corasón y ánima, cristiano" (Guaman Poma 1615: 925). Jorge Urioste (en Guaman Poma 1615: 925) traduce las dos frases: "Nuestra cristiandad emerge y aumenta. Esto debes ponderar, cristiano, en tu corazón y tu alma”. Szemiński (1993: 259) lo precisa de esta manera: "Décimo: se multiplica y predomina nuestro ser cristiano. En esto pensarás en tu corazón y ánima". En ambas traducciones se nombra el presente y se anticipa el futuro: se pronostica, o por lo menos se expresa la esperanza o la expectativa, de la expansión del cristianismo en el Perú. Veremos cómo "leer" estos sentimientos en los elementos gráficos del mapamundi, igual que los percibimos en el mismo mapa-dibujo la propuesta de Guaman Poma a Felipe III para la restauración de la soberanía andina (GP 975), haciendo eco de la de Las Casas a Felipe II de cincuenta años atrás.

A pesar de ser el "monarca del mundo" una figura céntrica en el mapamundi, Guaman Poma no lo pinta; sólo lo describe. El centro lo ocupará el rey Felipe III, "que no tiene jurisdicción", y entre los otros reyes, identificados sólo cultural 
o geográficamente, acompañará al monarca español el hijo de Guaman Poma, el bisnieto de Tupac Yupanqui Inca, como "el rey de las Indias". No vemos ni el rey español ni el príncipe andino. ¿Por qué? Porque los dos no pertenecen ni al presente ni al pasado sino al futuro ("a de ser monarca", "a de tener en esta corte", "estará en medio. . la magestad", "an de ser asalareados"; Guaman Poma 1615: 963). Recordemos que Guaman Poma (1615:962) escribió que, una vez que el Inca le había dado la corona a Guaman Chaua, nombrándolo uno de los cuatro reyes del imperio, "no se las quitaua jamás a sus hijos ni a sus nietos". Recordemos que al nuevo príncipe, con su doble ascendencia incaica y pre-incaica, lo coloca Guaman Poma en la posición de Collaysuyo, la de hurin, a la mano izquierda del rey español, el "monarca del mundo" que ocupa el centro. Pero no los vemos. No los vemos porque representan el futuro. Pero, ¿por qué colocar el príncipe de las Indias en hurin? Porque la ascendencia de este "monarca del mundo" (los tres reyes reunidos en la sexta edad, la de la conquista) mataron a reyes, mataron a los reyes incas. Al ver a un rival, "luego le mata o procura matalle", descoronándolo para "quedar solo" en el mando.

Como ya anticipamos, la figura de Túpac Inca Yupanqui tiene una pertinencia central a la conceptualización del pasado y el futuro en la Nueva corónica y buen gobierno. Esta idea la concretiza Guaman Poma en el mapamundi. El que ocupa el eje es Tupac Yupanqui Inca, respaldado por los símbolos de la Iglesia y del monarca español. Este es el modelo de "las Indias del Perú", y es en parte histórico (la figura de Tupac Yupanqui Inca) -arquetípico, diría Ossio (200)- y en parte profético (los símbolos del "monarca sin jurisdicción", y del triunfo anticipado del cristianismo). En el futuro proyectado por Guaman Poma el "rey cristiano sin jurisdicción" ocupará en el mapamundi el lugar de Tupac Ynca Yupanqui, y su descendiente, es decir, el hijo de Guaman Poma, se colocará en el lugar de su ancestro, Guaman Chaua.

La empresa de Guaman Poma es así en gran medida profética. Lo vemos en sus cronologías dinásticas y su gran capítulo, "Conquista", en cuanto al pasado, y especialmente en su proyección hacia el futuro en el de las "Conzederaciones". Al tomar en cuenta el pasado andino, Guaman Poma lo saca de la oscuridad, de "las tinieblas" de la ignorancia. Esta interpretación puede parecer demasiado especulativa para ser convincente. Pero volvamos una vez más al texto en prosa de la Nueva corónica donde surge esta interpretación.

Si las seis edades del mundo según Jerónimo Chaves se convirtieron en las primeras cinco del mundo en Guaman Poma, las otras cinco que las siguen abrieron camino a un futuro, en parte realizado (la sexta hasta la novena edad, inclusive), en parte por venir (la décima edad). Las edades novena y décima de "las edades de las Indias del Perú" proveen el último elemento que me permite atribuir al mapamundi estos valores del pasado y el futuro. Como 
los mapamundi medievales cristianos que concibieron e hicieron convergir el Jerusalén terrestre, el Jerusalén mesiánica y el Jerusalén espiritual, el Cuzco del mapamundi de Guaman Poma conceptualiza un Cuzco terrestre, un Cuzco mesiásico y un Cuzco espiritual (icelestial?); esto es, un Cuzco terrestre gobernado por el orden de las instituciones fundadas por Tupac Inca Yupanqui, un Cuzco mesiánico orientado por la evangelización y la fe cristiana, y un Cuzco espiritual, profetizado para permanecer "en el archivo del cielo como en el del mundo", por su grandeza sin par:

Aves de conzederar que tan gran magestad que tenía el Ynga Topa Ynga Yupanqui, rrey del Pirú y Guayna Capac Ynga que se a leydo todas las historias y corónicas del mundo de los rreys y príncipes, enperadores del mundo, ací cristianos como del Gran Turco y del rrey chino, enperadores de Roma y toda la cristiandad y de judíos y del rrey de Guinea. No he hallado a nenguno que aya cido tan gran magestad (Guaman Poma 1615: 962).

El antiguo rey de Chinchaysuyo, Guaman Chaua, será reemplazado por su bisnieto, es decir, el hijo de Guaman Poma, que no será rey del Chinchaysuyo, sino de todas "Las Indias al Perú" ("América"). Se encontrará al lado de los otros reyes autónomos en sus dominios de África ("Guinea”), Europa ("los cristianos de Roma") y el Medio Oriente ("los moros del Gran Turco"). Es un orden global en el que "las Indias del Perú" formará una parte integral y clave.

En fin, hemos podido apreciar el modelo de Tawantinsuyu, representado gráficamente en el mapamundi de Guaman Poma, y vimos como su autor, basándose en el modelo antiguo andino, también siguió a Las Casas al concebir un orden político universal del futuro. Hemos podido percibir en el mapamundi de Guaman Poma no sólo el modelo del orden andino antiguo sino otro, igualmente consagrado: el patrón medieval cristiano que, en una economía impresionante de símbolos gráficos, da forma y sentido a la historia de la humanidad: Jerusalén, donde la calavera de Adán descansa al pie de la cruz del Cristo crucificado, Jerusalén, que representa tanto la creación de la humanidad (Adán) como su último destino, la salvación espiritual (Jesucristo). Atento a esa disposición gráfica y su significado, Guaman Poma, sustituyendo Jerusalén por el Cuzco, y Adán y Cristo por Tupac Inca Yupanqui y los emblemas de la monarquía española y la iglesia romana, elabora su propia versión del modelo del destino histórico y trascendente andino (y universal): Cuzco, donde todo lo instituido por Tupac Ynca Yupanqui como fundador estará respaldado por las instituciones auxiliares europeas, Cuzco, donde nació y creció el imperio de los Andes y cuyo destino lo cumplirán los nuevos príncipes andinos.

En total, el mapamundi de la Nueva corónica y buen gobierno, interpretado con la ayuda de sus textos en prosa complementarios, y tomando en cuenta sus 
fuentes y los modelos externos que enriquecen su lectura, postula una suerte de vuelta a los orígenes, recuperación del paraíso perdido y restauración del orden: profetiza la inauguración del antiguo orden andino renovado y actualizado, pero con una diferencia. Esta diferencia es una marca permanente: el mundo andino de las Indias del Perú está configurado en el orden global, sí, pero en la posición de hurin, gracias a su incorporación en un orden cuyos soberanos matan a reyes, cometen regicidios. No lo vemos en el mapamundi tal cual, pero sí en su coordinación con el texto en prosa, en el conjunto de mapa y crónica. Todos estos principios, reunidos gráficamente en el mapamundi, apuntan hacia un futuro, ese futuro que será para Guaman Poma "el fin de la historia". Pronostica no un futuro idealizado sino un futuro manchado. El mapamundi es un ejemplo, como escribí (Adorno 1992:181, 185) hace muchos años, "de las semillas de su desconcierto" que esparce a lo largo del libro, y es-pienso de nuevo en el mapamundi-"uno de los primeros esfuerzos por encontrar una respuesta, real y práctica, a las concepciones-civiles y eclesiásticas-creados por los 'otros”', los otros que existen más allá de las cuatro partes del mundo, del mundo, es decir, de las Indias del Perú.

\section{Referencias bibliográficas}

ADORNO, Rolena (1978a): "Felipe Guaman Poma de Ayala: An Andean View of the Peruvian Viceroyalty, 1565-1615” en Journal de la Société des Américanistes, 65, pp. 121-143. 1o de septiembre de 2014, 18 h. http://www.kb.dk/permalink/2006/ poma/info/en/docs/index.htm

ADORNO, Rolena (1978b): "Las otras fuentes de Guamán Poma: sus lecturas castellanas" en Histórica, 2, pp. 137158.

ADORNO, Rolena (1979a): "Icon and idea: A Symbolic Reading of the Visual Text of Guaman Poma” en The Indian Historian, 12, 3, pp. 2750.

ADORNO, Rolena (1979b): "Paradigms Lost: A Peruvian Indian Surveys Spanish Colonial Society" en Studies in the Anthropology of Visual Communication, 5, pp. 7896.

ADORNO, Rolena (1984): "Paradigmas perdidos: Guamán Poma examina la sociedad española colonial” en Revista Chungará, 13, pp. 6791.

ADORNO, Rolena (1986). Guaman Poma: Writing and Resistance in Colonial Peru. Austin: University of Texas Press.

ADORNO, Rolena (1989). Cronista y príncipe: La obra de Don Felipe Guaman Poma de Ayala. Lima: Pontificia Universidad Católica del Perú.

ADORNO, Rolena (1992). Guaman Poma:literatura de resistencia en el Perú colonial. Traducción de Martín Mur U. México: Siglo Veintiuno.

ADORNO, Rolena (2002): "A Witness unto Itself: The Integrity of the Autograph Manuscript of Felipe Guaman Poma de Ayala's Nueva corónica y buen gobierno (16151616)" en Fund og Forskning, 41, pp. 7-106. 10 de septiembre de 2014, 18 h. http://www.kb.dk/permalink/2006/poma/info/en/docs/index.htm 
El fin de la historia en la Nueva corónica y buen gobierno de Felipe Guaman Poma de Ayala

BARNES, Mónica (1995). “Las edades del hombre y del mundo”. En: Humanismo: Siglo XX. Estudios dedicados al Dr. Juan Adolfo Vázquez. San Juan, Argentina, pp. 291-297.

BLACK, Jeremy (1997). Maps and History: Constructing Images of the Past. New Haven and London: Yale University Press, 1997.

CASAS, Bartolomé de las (1958) [1562]. Tratado de las doce dudas. En: Juan Pérez de Tudela Bueso (ed.) Obras escogidas de Fray Bartolomé de las Casas, V. Madrid: Atlas. pp. 478-536.

FLEMING, David (1994): "Guaman Poma, Hieronymo de Chaues and the Kings of Persia" en Latin American Indian Literatures Journal, 10, 1, pp. 46-60.

FUKUYAMA, Francis (1992). The End of History and the Last Man. New York: The Free Press.

GONZÁLEZ HOLGUín, Diego. Vocabulario de la lengua general de todo el Perú llamada lengua qquichua o del Inca. 1608, 1952. Presentación Ramiro Matos Mendieta, prólogo de Raúl Porras Barrenechea. Lima: Universidad Nacional Mayor de San Marcos, 1989.

GUAMAN POMA DE AYALA, Felipe $(1980,2004)$ [1615]. John V. Murra, Rolena Adorno (eds.), trad. del quechua de Jorge Urioste. El primer nueva corónica y buen gobierno. México: Siglo Veintiuno.

GUAMAN POMA DE AYALA, Felipe (1615). El primer nueva corónica y buen gobierno. GkS 2232, $4^{0}$, Biblioteca Real, Copenhague, Dinamarca. 10 de septiembre de 2014, 12.00 h. http://www.kb.dk/permalink/2006/poma/info/es/frontpage.htm.

LÓPEZ-BARALT, Mercedes (1979a): "La persistencia de las estructuras simbólicas andinas en los dibujos de Guaman Poma de Ayala” en Journal of Latin American Lore, 5, 1, pp. 83-116.

LÓPEZ-BARALT, Mercedes (1979b): "La Contrarreforma y el arte de Guaman Poma: notes sobre una política de comunicación visual” en Histórica, 3, pp. 81-95.

LÓPEZ-BARALT, Mercedes (1982): "La crónica de Indias como texto cultural: articulación de los códigos icónico y linguiístico en la nueva corónica de Guaman Poma” en Revista Iberoamericana, 43, 120-121, pp. 461-531.

LÓPEZ-BARALT, Mercedes (1988). Ícono y conquista: Guaman Poma de Ayala. Madrid: Hiperión.

MILHOU, Alain (1983). Colón y su mentalidad mesiánica en el ambiente franciscanista español. Valladolid: Casa Museo de Colón, Seminario Americanista de la Universidad de Valladolid.

OSSIO, Juan (1973). "Guaman Poma: Nueva corónica o carta al rey. Un intento de aproximación a las categorías del pensamiento del mundo andino”. En: Juan Ossio (ed.) Ideología mesiánica del mundo andino. Lima: Ignacio Prado Pastor, pp. 153213.

PLAS, Sophie (1996): “Une source européenne de la Nueva corónica y buen govierno de Guaman Poma” en Journal de la Société des Américanistes 82, pp. 97-116.

SZEMIÑSKI, Jan (1993). "Textos andinos de Don Felipe Guaman Poma de Ayala”. En: Felipe Guaman Poma de Ayala, Nueva corónica y buen gobierno, Franklin Pease G. Y. (ed.). Lima, Perú: Fondo de Cultura Económica, vol. 3, pp. 161-267.

VEGA, Garcilaso de, El (1963) [1609]. Primera parte de los Comentarios reales de los Incas. En: Carmelo Sáenz de Santa María (ed.) Obras completas del Inca Garcilaso de la Vega, II. Madrid: Atlas.

LETRAS 85 (121), 2014 
Rolena Adorno

WACHTEL, Nathan (1973). "Pensamiento salvaje y aculturación: el espacio y el tiempo en Felipe Guaman Poma de Ayala y el Inca Garcilaso de la Vega”. En: Nathan Wachtel. Sociedad e ideología: ensayos de historia y antropología andinas. Lima: Instituto de Estudios Peruanos, pp. 165-228. 